\title{
Another pass of the torch
}

\section{Une autre transmission du flambeau}

I $\mathrm{t}$ is with some trepidation and much humility that I take on the role of Editor-in-Chief (EiC) of the Canadian Respiratory Journal (CRJ). I have been passed the baton by a couple of Canadian legends in respiratory medicine: Dr Nicholas Anthonisen, the immediate past $\mathrm{EiC}$ and, before him, Dr Norman Jones, the inaugural EiC. A tough duo to follow!

Norman Jones was $\mathrm{EiC}$ between 1994, when the Journal was born, until Volume 8, issue 6 in 2001. He edited 47 issues of the CRJ and, in 2000, began a tradition I will not attempt to emulate - contributing an editorial to each issue. Nick Anthonisen has been the EiC since 2001, and has supervised the publication of 70 issues of the Journal contributing an editorial to almost every issue - a total of 61 editorials. The subject matter of these editorials was amazingly diverse and, among others, included the following: Canadian normal lung function values, transplant bronchiolitis obliterans, First Nations pneumonia admissions, the use of inhaled steroids in chronic obstructive pulmonary disease (COPD), management and outcome of malignant mesothelioma in Anatolia, Turkey, and the value of case reports in the medical literature.

That Nick was able to provide erudite, informed and entertaining commentary on such a wide range of subjects is a testament to his stature as a renaissance man in respiratory medicine. Nick has had a long and distinguished career in Canada after coming from Dartmouth College (USA) to join the Division of Respiratory Medicine at McGill University (Montreal, Quebec) in 1964. He was an active clinician investigator and my Respiratory Training Program Director at McGill in

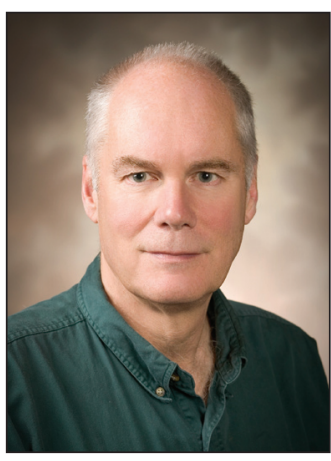

Peter Paré, Editor-in Chief

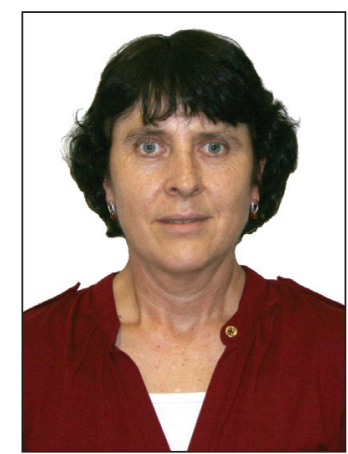

Katherine Thain, Editorial Assistant

C'est avec une certaine trépidation et beaucoup d'humilité que j'accepte le rôle de rédacteur en chef (ReC) de la Revue canadienne de pneumologie (RCP). Quelques légendes canadiennes de la médecine pulmonaire m'ont passé le relais, soit le docteur Nicholas Anthonisen, $\mathrm{ReC}$ sortant et, avant lui, le docteur Norman Jones, premier ReC.Un duo auquel il est difficile de succéder!

Norman Jones a été ReC de 1994, à la création de la Revue, jusqu'au numéro 6 du volume 8 , en 2001. Il a édité 47 numéros de la RCP et, en 2000, a lancé une tradition que je ne tenterai pas d'émuler, la publication d'un éditorial à chaque numéro. Nick Anthonisena été $\mathrm{ReC}$ à compter de 2001 et a supervisé la publication de 70 numéros de la Revue, rédigeant un éditorial dans la quasi-totalité d'entre eux, pour un total de 61 éditoriaux. Ces éditoriaux étaient d'une étonnante diversité et ont porté, entre autres, sur les sujets suivants : les valeurs canadiennes de la fonction pulmonaire normale, la bronchiolite oblitérante chez les greffés, les hospitalisations attribuables à la pneumonie au sein des Premières nations, l'utilisation de la corticothérapie par aérosol contre la maladie pulmonaire obstructive chronique (MPOC), la prise en charge et l'issue du mésothéliome malin en Anatolie, en Turquie, et la valeur des rapports de cas dans les publications médicales.

Que Nick ait pu fournir des commentaires érudits, informés et divertissants sur des sujets aussi variés témoigne de son esprit universel en médecine pulmonaire. Nick a mené une longue et éminente carrière au Canada après avoir quitté le Dartmouth College (États-Unis) en 1964, pour travailler à la division de la médecine pulmonaire de 1974, and subsequently took on the role of Respiratory Division head and, later, Dean at the University of Manitoba (Winnipeg, Manitoba), where he remains an active Emeritus faculty member and clinician. He has made major contributions to our understanding of the pathogenesis and management of lung diseases, particularly COPD, through his leadership in four of the most definitive and influential respiratory clinical trials ever conducted (1-4).

Under the leadership of Drs Jones and Anthonisen, the CRJ has grown in stature and has become an important means of communication and education for the medical community in Canada and internationally. How does one judge the stature of a medical journal? One metric is the impact factor (IF). The IF is a measure of how frequently original articles appearing in a journal are cited in the medical literature. The IF is derived by dividing the number of times articles published over the preceding two years are cited in the current year. For example, if a journal has an IF of 2 for the year 2010, it means that the articles published in that journal during 2008 and 2009 received an average of two citations in 2010; it could be that all of the citations were for only a few of the articles, so it is a measure of the journal's impact, not the impact of individual articles or their authors. The CRJ's present impact factor is 1.347 because in 2010 there were 101 citations of the 75 articles published in 2008 and 2009 (ie, 101/75=1.347). This is an increase from 1.0 in 2009. The CRJ ranks 36th among the 46 respiratory specialty journals listed on the ISI Web of Knowledge; the highest ranked are The American Journal of Respiratory and Critical Care Medicine (the 'Blue Journal') at 10.191, Thorax at 6.525, Chest at 6.519 and the European Resipratory Journal at 5.922.

The IF is easily measured, but has limited validity $(5,6)$. Problems include marked variation according to discipline, 'self citation' - in l'Université McGill, à Montréal, au Québec. C'était un chercheurclinicien actif et mon directeur de programme de formation en pneumologie à McGill en 1974. Il est ensuite devenu chef de la division de pneumologie puis, plus tard, doyen à l'université du Manitoba, à Winnipeg, où il demeure professeur émérite et clinicien. Il a eu un apport majeur à notre compréhension de la pathogenèse et de la prise en charge des maladies pulmonaires, notamment la MPOC, par sa direction de quatre des essais pneumologiques cliniques les plus décisifs et influents jamais menés (1-4).

Sous la direction des docteurs Jones et Anthonisen, la RCP a pris de l'envergure et est devenue un important moyen de communication et de formation pour le corps médical du Canada et du monde. Comment évalue-t-on l'envergure d'une revue médicale ? Le facteur d'impact (FI) fait partie des paramètres utilisés. Le FI est une mesure de la fréquence des citations d'articles originaux dans les autres publications médicales. Il est calculé en divisant le nombre de fois où les articles publiés au cours des deux années précédentes sont cités pendant l'année courante. Par exemple, si une revue a un FI de 2 pour l'année 2010, les articles qui y ont été publiés en 2008 et 2009 ont été cités en moyenne deux fois en 2010. Il se peut que toutes les citations proviennent de quelques articles seulement. C'est pourquoi le résultat reflète l'impact de la revue et non celui de chaque article ou de leurs auteurs. Le FI actuel de la RCP est de 1,347 parce qu'en 2010, les 75 articles publiés en 2008 et 2009 ont été cités 101 fois (c'est-à-dire 101/75=1,347). C'est une augmentation par rapport au facteur de 1,0 en 2009. La RCP arrive au $36^{\mathrm{e}}$ rang sur les 46 revues spécialisées en pneumologie figurant dans le Web of Knowledge d'ISI. Les premières places sont occupées par The American Journal of 
which authors cite their own publications inordinately often - and gaming by journals to reduce the number of 'citable' articles that go into the denominator of the IF (for example, editorials are not considered 'citable', but review articles are and these can substantially inflate the IF).

A metric that would really measure the impact of a journal would be the product of how many people involved in patient care read the journal multiplied by the positive effect that the reading had on the care of the patients they serve. No such metric exists, but we do know the number of people who get the print copy of the CRJ. It is distributed to 13,000 health care providers in Canada. These include the 615 Canadian Thoracic Society (CTS) members (as a benefit of membership), an additional 370 practitioners who have respiratory expertise/ interest, 700 with an interest in otolaryngology, 300 with an interest in Allergy, 650 with an interest in infectious disease, 500 emergency room physicians, 200 geriatricians and 9000 family practitioners who have, based on their prescriptions, an interest in respiratory disorders. The other way to access the CRJ is online. Up to May 2011, there were 14,173 page views, 4677 visits, 2413 unique visitors and an average length of visit of 3 min $42 \mathrm{~s}$.

There is not, as far as I know, any metric to assess how the receipt and reading of a journal influences clinical practice. The CRJ has published an increasing number of clinical practice guidelines (CPGs) and one might expect that these publications reaching a large number of practitioners could have a substantial impact on clinical practice and patient care. However, despite the substantial resources that have been spent developing CPGs, there is a paucity of data measuring the impact of CPGs on the process of practice and on patient outcomes. A systematic review performed in Holland in 2009 (7) showed that 17 of 19 studies that assessed the effects of guidelines on the process or structure of care showed significant improvements, while six of nine studies in which measures of patient health outcomes were assessed showed significant but small improvements. If CPGs are to have an impact on changing behaviour, more effective implementation will be needed; a group from the College of Respiratory Therapists of Ontario have recommended guidelines for successful implementation (8).

Additional measures of a journal's 'performance' include the time from submission to review, from submission to acceptance and from acceptance to publication. Norman Jones reviewed these data for the final two years of his tenure based on 161 submissions. The mean time from submission to review was $4.4 \pm 2.5$ weeks, between submission and acceptance was $16 \pm 9$ weeks and from submission to publication was $30 \pm 12$ weeks. The difference between the latter two intervals 14 weeks - is the delay from acceptance to publication ( 3.5 months). The rejection rate was $18 \%$, and $26 \%$ of submissions were case reports.

Nick Anthonisen reviewed his first 18 months as EiC in June 2003. Over that time period, he received 84 original articles including case reports (56 per year). Of these, 66 were from Canada, with 18 (21\%) from outside of Canada. The rejection rate was $25 \%$ and Nick lamented the delay of six months from acceptance to publication for an article.

Nick reviewed performance again in 2005. During 2004/2005, 70 manuscripts were submitted, 26 of which were of non-Canadian origin $(37 \%)$ and $33 \%$ were rejected. The time from submission to review and decision remained remarkably short, but the average time from acceptance to publication had increased to six months. Unfortunately, this metric of performance has not improved. For 2010 , the average time from acceptance to publication was seven to 10 months - this is too long.

When I started as EiC on May 1, 2011, the CRJ converted to a fully online submission process. As I write this (July 9, 2011), we have received 37 submissions (a rate of 190 per year). Of these, $75.7 \%$ are of non-Canadian origin and 14 are case reports (37.8\%). It is too early to predict the rejection rate but with six issues per year and an average of eight to 10 items per issue, the rejection rate will likely be approximately $75 \%$, a big jump since the $18 \%$ rejection reported by Norman Jones in 2001 !
Respiratory and Critical Care Medicine (la « revue bleue »), avec un facteur de 10,191, Thorax, de 6,525, Chest, de 6,519, et l'European Respiratory Journal, de 5,922.

Le FI est facile à mesurer, mais a une validité limitée $(5,6)$. Parmi les problèmes, on constate des variations marquées selon les disciplines, l'autocitation (les auteurs citent leurs propres publications à une fréquence excessive) et les manœuvres des revues pour réduire le nombre d'articles pouvant être cités inclus dans le dénominateur du FI (par exemple, les éditoriaux ne sont pas considérés comme " citables », mais les exposés de synthèse le sont et peuvent accroître considérablement le FI).

Le produit du nombre de personnes qui participent aux soins aux patients et qui lisent le journal multiplié par l'effet positif de cette lecture sur les soins aux patients dont ils s'occupent serait un paramètre qui mesurerait vraiment l'impact d'une revue. Il n'existe pas de tel paramètre, mais on sait combien de personnes reçoivent un exemplaire imprimé de la RCP. La revue est distribuée à 13000 dispensateurs de soins au Canada, dont les 615 membres de la Société canadienne de thoracologie (SCT, dans le cadre des avantages aux membres), 370 autres praticiens qui ont des compétences ou un intérêt en pneumologie, 700 qui s'intéressent à l'otorhinolaryngologie, 300 qui s'intéressent aux allergies, 650 qui s'intéressent à l'infectiologie, 500 médecins d'urgence, 200 gériatres et 9000 médecins de famille qui, selon leurs ordonnances, s'intéressent aux troubles respiratoires. On peut également accéder à la RCP par voie électronique. En mai 2011, on dénombrait 14173 pages vues, 4677 visites, 2413 visiteurs uniques et une durée moyenne de 3 minutes 42 secondes par visite.

Pour autant que je sache, aucun paramètre n'évalue en quoi la réception et la lecture d'une revue influent sur la pratique clinique. La RCP a publié un nombre croissant de guides de pratique clinique (GPC). On s'attendrait que la diffusion de ces publications auprès d'un grand nombre de praticiens aurait un impact considérable sur la pratique clinique et les soins aux patients. Cependant, malgré les ressources importantes allouées à l'élaboration des GPC, peu de données mesurent l'impact des GPC sur le processus de la pratique et les issues des patients. Une analyse systématique effectuée en Hollande en 2009 (7) a révélé que 17 des 19 études qui évaluaient les effets des lignes directrices sur le processus ou la structure des soins démontraient des améliorations marquées, tandis que six des neuf études dans lesquelles on mesurait les issues de santé des patients révélaient des améliorations significatives, mais tout de même modestes. Si les GPC n'ont pas d'impact sur les changements de comportement, il faudra les diffuser de manière plus efficace. Un groupe du College of RespiratoryTherapists of Ontario a recommandé des lignes directrices sur une mise en œuvre réussie (8).

Parmi les autres mesures de rendement d'une revue, soulignons le délai entre la soumission et la révision, entre la soumission et l'acceptation et entre l'acceptation et la publication. Norman Jones a analysé ces données pendant les deux dernières années de son mandat, compte tenu de 161 soumissions. Le délai moyen entre la soumission et la révision était de 4,4 $\pm 2,5$ semaines, entre la soumission et l'acceptation, de $16 \pm 9$ semaines, et entre la soumission et la publication, de $30 \pm 12$ semaines. La différence de 14 semaines entre les deux derniers intervalles correspond au délai entre l'acceptation et la publication (3,5 mois). Le taux de rejet s'élevait à $18 \%$, et $26 \%$ des soumissions étaient des rapports de cas.

Nick Anthonisen a évalué ses 18 premiers mois comme ReC en juin 2003. Pendant cette période, il a reçu 84 articles originaux, y compris des rapports de cas ( 56 par année). De ce nombre, 66 provenaient du Canada, et 18 (21\%), de l'extérieur du Canada. Le taux de rejet s'élevait à $25 \%$, et Nick déplorait le délai de six mois entre l'acceptation et la publication d'un article.

Nick a analysé de nouveau le rendement en 2005. En 2004-2005, 70 manuscrits ont été soumis, dont 26 n'étaient pas d'origine canadienne (37\%), et $33 \%$ ont été rejetés. Le délai entre la soumission et la révision et la décision était demeuré remarquablement court, mais le délai moyen entre l'acceptation et la publication était passé à six mois. 
This brief history illustrates the following trends: increasing submissions and increasing percentage of submissions from non-Canadian origins (both good!), an increasing percentage of case reports (good?) and a lengthening of time from acceptance to publication (bad!). How are we to shorten this interval? There are two ways: increase the number of published articles or reject more manuscripts. The number of pages of articles that appear in the hard copy version of the Journal is limited and is based on the advertising revenue generated by Pulsus. It is largely this revenue that supports the substantial infrastructure necessary to edit and publish the CRJ. The current limit is 56 pages per issue. Contributors can 'buy' extra pages, and this is what the CTS does to publish its guidelines and position papers. Thus, increasing the number of published papers to shorten the time between acceptance and publication is not simply a matter of putting out a few extra thick issues to clear the backlog unless additional funding sources can be found.

However, there is the option to increase the number of papers published 'online only'. The CRJ began this with the May/June issue (Volume 16, number 3) in 2009 and the percentage of articles published in this way has increased. There were 105 pages of 'online only' material in the $2010 \mathrm{CRJ}$ with no advertising. Health Canada does not allow online medical advertising because the site is accessible to the general public as well as to the medical community. Our practice is to offer 'online only' publication to authors with the 'carrot' being more rapid publication. Surprisingly, most want to wait and have their articles appear in print. I find this surprising because it seems to me that the way the world is going is toward almost exclusive online publishing. I have given up all of my hardcopy journals - except the CRJ, of course! I receive notification of the table of contents of the journals I subscribe to, and access to the abstracts and articles via the journal websites or through my University library, which subscribes to most of the journals I read. Although it might seem obvious that a move to online only for the whole journal is the way of the future, it leaves the question of how this would be funded. With no online advertising, the only option is to charge the subscribers and/or the authors. Openaccess, online-only journals pass the costs of reviewing, editing and running the journal's web site on to the authors. The obvious advantages are rapid turnaround time and universal access, but many people still want the hard copy of journals so that they can send them to their mothers or read them in bed!

Clearly, the future of medical publishing is in flux. Our plan to decrease the delay between acceptance and publication is to work with Pulsus and the CTS to encourage more advertising (and thus more pages per issue and/or more issues per year), to continue to offer faster publication online only and to be more stringent in the quality of the articles that we accept.

The CRJ is the official journal of the CTS, which appoints the editors and determines editorial policy. In April of this year, I developed a vision for how I would enhance the CRJ as EiC and presented it to the Editorial Board. My philosophy and goals are summarized below.

I believe that the CRJ is an important instrument of communication and education for the Canadian respiratory community. I believe that it should primarily be a clinical journal dedicated to research, guidelines and clinical issues concerning human pulmonary disease and lung health. To increase the readership and the impact of the journal, aims for my editorship include the following:

1. Implement the online submission and review process.

2. Appoint a new slate of associate editors who have specific expertise in focused clinical areas, and who take an active part in the selection of papers for the Journal and write editorials and review articles in their area of expertise.

3. Appoint an editorial assistant who will work with the $\mathrm{EiC}$ and associate editors to facilitate the running of the Journal.

4. Increase the breadth of the contributing and reading community by forming partnerships with specific groups:
Malheureusement, ce paramètre de rendement ne s'est pas amélioré. En 2010, le délai moyen entre l'acceptation et la publication était de sept à dix mois. C'est trop long.

Lorsque je suis devenu ReC le $1^{\text {er }}$ mai 2011, la RCP est passée à un processus de soumission entièrement électronique. Tandis que je rédige ces lignes (le 9 juillet 2011), nous avons reçu 37 soumissions (un taux de 190 par année). De ce nombre, 75,7\% sont d'origine non canadienne et 14 sont des rapports de cas $(37,8 \%)$. Il est trop tôt pour prédire le taux de rejet, mais puisqu'il y a six numéros par année et une moyenne de huit à dix articles par numéro, le taux de rejet s'élèvera probablement à $75 \%$, un bond remarquable depuis les $18 \%$ déclarés par Norman Jones en 2001 !

Ce bref historique reflète les tendances suivantes : augmentation des soumissions et augmentation du pourcentage de soumissions d'origine non canadienne (deux bonnes nouvelles !), pourcentage croissant de rapports de cas (bonne nouvelle ?) et allongement du délai entre l'acceptation et la publication (mauvaise nouvelle !) Comment réduire cet intervalle ? De deux façons : accroître le nombre d'articles publiés ou rejeter plus de manuscrits. Le nombre de pages d'articles qui sont publiés dans la version papier de la Revue est limité et dépend des revenus publicitaires générés par Pulsus. C'est en grande partie ces revenus qui soutiennent l'importante infrastructure nécessaire pour éditer et publier la RCP. La limite actuelle est fixée à 56 pages par numéro. Les collaborateurs peuvent « acheter » des pages supplémentaires, et c'est ce que fait la SCT pour publier ses lignes directrices et ses documents de principes. Ainsi, l'augmentation du nombre d'articles publiés pour réduire le délai entre l'acceptation et la publication ne se limite pas à la préparation de quelques numéros très épais pour se débarrasser des articles accumulés, à moins de dénicher de nouvelles sources de financement.

Cependant, on peut accroitre le nombre d'articles publiés « seulement par Internet ». La RCP a adopté cette pratique dans le numéro de maijuin (volume 16, numéro 3) 2009, et le pourcentage d'articles publiés de cette façon a augmenté. On recensait 105 pages d'articles de la RCP publiés « seulement par Internet " en 2010, sans publicité. En effet, Santé Canada interdit la publicité médicale par Internet parce que le site est accessible au public tout autant qu'au corps médical. Nous avons l'habitude d'offrir la publication « seulement par Internet » aux auteurs, en leur offrant la « carotte » d'une publication plus rapide. Fait surprenant, la plupart préfèrent attendre la publication papier. Je trouve cette tendance surprenante, parce qu'il me semble que le monde évolue vers des publications presque exclusivement électroniques. J'ai laissé tomber toutes mes revues imprimées, sauf la RCP, bien sûr ! Je reçois la table des matières des revues auxquelles je suis abonné, et j'accède aux résumés et aux articles par le site Web des revues ou par ma bibliothèque universitaire, qui est abonnée à la plupart des revues que je lis. Il peut sembler évident que la voie de l'avenir serait de passer à une revue uniquement électronique, mais cette transition ne tient pas compte du financement. Sans publicité électronique, la seule possibilité consiste à facturer les abonnés ou les auteurs. Les revues virtuelles à libre accès transfèrent les coûts de révision, d'édition et de tenue du site Web aux auteurs. Les avantages évidents sont des délais rapides et un accès universel, mais bien des gens veulent encore la copie papier de la revue pour l'envoyer à leur mère ou la lire au lit !

De toute évidence, l'avenir des publications médicales est en transformation. Pour réduire le délai entre l'acceptation et la publication, nous planifions travailler avec Pulsus et la SCT pour favoriser plus de publicité (et donc plus de pages par numéro ou plus de numéros par année), de continuer d'offrir une publication plus rapide par Internet et d'être plus rigoureux quant à la qualité seulement des articles acceptés.

La RCP est la revue officielle de la SCT, qui nomme les rédacteurs et détermine la politique éditoriale. En avril, j'ai élaboré une vision sur la manière dont j'améliorerais la RCP si je devenais ReC et l'ai présentée au comité de rédaction. Ma philosophie et mes objectifs sont résumés ci-dessous. 
a. Critical care community

b. Respiratory sleep community

c. Pulmonary pediatric community

d. Thoracic surgery community

e. Respiratory rehabilitation and respiratory therapy communities

5. Implement a clinical-radiological-pathological conference report that would regularly be contributed to by specific groups across the country.

6. Publish high-quality reviews by prominent Canadian clinician scientists on specific important and timely clinical issues of diagnosis and treatment.

7. Develop a pulmonary fellows forum in which experienced clinicians dispense 'pearls' for trainees.

8. Increase the role of the Journal as a vehicle for the dissemination of practice guidelines developed by the CTS and other pertinent subspecialty groups.

Some of these goals have been acted on already, and I take this opportunity to introduce our new editorial assistant Ms Katherine Thain. Katherine, who is working part time with me and the associate editors, is a $\mathrm{PhD}$ candidate at the University of British Columbia (Vancouver, British Columbia) and is interested in determining whether a career in medical publishing is part of her future. We have appointed a new group of Associate Editors with specific expertise, which include the following:

- Asthma: Louis-Philippe Boulet, Laval University, Quebec City, Quebec

- COPD: Denis E O’Donnell, Queen's University, Kingston, Ontario

- Interstitial Lung Disease: Charlene Fell, University of Calgary, Calgary, Alberta

- COPD and Respiratory Muscles: Francois Maltais, Laval University

- Pulmonary Vascular Disease: Evangelos Michelakis, University of Alberta, Edmonton, Alberta

- Rehabilitation Medicine: Dina Brooks, University of Toronto, Toronto, Ontario

- Tuberculosis: Kevin Schwartzman, McGill University, Montreal, Quebec

- Cystic Fibrosis: Liz Tullis, University of Toronto

- Pediatric Pulmonary Disease: Felix Ratjen, University of Toronto

- Environmental and Occupational: Catherine Lemiere, University of Montreal, Montreal, Quebec

- Lung Cancer: Stephan Lam, University of British Columbia

- Pulmonary Imaging: Jonathon Lepisic, University of British Columbia

- Interventional Pulmonology and Procedures: Alain Tremblay, University of Calgary.

An additional new Associate Editor, Dr George Rakovich from the University of Montreal, is drafting guidelines for a regular clinicalimaging-pathological educational forum that he will be in charge of and we will invite all Pulmonary and Thoracic Surgery Programs to participate. We have asked the executives of the Canadian Sleep Society and the Canadian Critical Care Society to recommend Associate Editors for these disciplines, and we are exploring more formal relationships between these Societies and the CRJ.

I want to take this opportunity to thank the generosity of 'retiring' Associate Editors and Editorial Board members, many of whom have served the Journal since its inception 18 years ago. These include Board members Margaret Becklake, Raymond Bégin and Moira Yeung, as well as Associate Editors, Art Slutsky, Zoheir Bshouty, Donald Cockcroft, Yvon Cormier, Mark FitzGerald, Richard Hodder, Michael Kay, Kieran Killian, Malcolm King, Jean Luc-Malo, Rob McFadden and Bruce Rubin, some of whom are staying on as Editorial Board members.

Finally, I welcome new Editorial Board members, Avrum Spira from Boston University (Massachusetts, USA), a displaced Canadian who is
Je pense que la RCP est un outil de communication et de formation important pour le milieu canadien de la pneumologie. Je pense qu'il devrait être surtout un journal clinique voué à la recherche, aux lignes directrices et aux problèmes cliniques liés aux maladies pulmonaires et à la santé pulmonaire chez les humains. Pour accroître le lectorat et l'impact de la revue, je chercherais à réaliser ce qui suit pendant mon mandat:

1. Mettre en œuvre le processus de soumission et de révision électronique.

2. Nommer un nouveau groupe d'éditeurs adjoints qui ont des compétences précises dans des secteurs cliniques ciblés et qui participent activement à la sélection des articles de la Revue, rédigent des éditoriaux et révisent les articles dans leur domaine de compétences.

3. Nommer un adjoint à la rédaction qui travaillera avec le ReC et les éditeurs adjoints afin de faciliter le fonctionnement de la Revue.

4. Accroître l'étendue du groupe de collaborateurs et de lecteurs grâce à des partenariats avec des groupes précis :

a. le milieu des soins intensifs,

b. le milieu du sommeil respiratoire,

c. le milieu de la pédiatrie pulmonaire,

d. le milieu de la chirurgie thoracique,

e. les milieux de la réadaptation pulmonaire et de la thérapie pulmonaire.

5. Mettre en œuvre un rapport des congrès cliniques-radiologiquespathologiques auquel collaboreraient régulièrement des groupes précis au pays.

6. Publier des analyses de qualité par d'éminents scientifiques cliniciens canadiens sur d'importants enjeux diagnostiques et thérapeutiques cliniques et d'actualité

7. Mettre sur pied une tribune d'associés en pneumologie dans laquelle des cliniciens d'expérience dispensent des «perles » aux stagiaires.

8. Accroitre le rôle de la Revue comme outil de diffusion des lignes directrices élaborées par la SCT et d'autres groupes de surspécialité pertinents.

Certains de ces objectifs sont déjà adoptés, et je profite de l'occasion pour vous présenter la nouvelle adjointe à la rédaction, madame Katherine Thain. Katherine, qui travaille à temps partiel avec moi et les éditeurs adjoints, est doctorante à l'université de la Colombie-Britannique, à Vancouver, et désire déterminer si une carrière en publication médicale l'intéresserait. Nous avons nommé un nouveau groupe d'éditeurs adjoints possédant des compétences précises, y compris les personnes suivantes :

- Asthme : Louis-Philippe Boulet, Université Laval, Québec (Québec)

- MPOC : Denis E O'Donnell, université Queen's, Kingston (Ontario)

- Maladie pulmonaire interstitielle : Charlene Fell, université de Calgary, Calgary (Alberta)

- MPOC et muscles respiratoires : François Maltais, Université Laval

- Maladies vasculaires pulmonaires : Evangelos Michelakis, université de l'Alberta, Edmonton (Alberta)

- Médecine de réadaptation : Dina Brooks, université de Toronto, Toronto (Ontario)

- Tuberculose : Kevin Schwartzman, Université McGill, Montréal (Québec)

- Fibrose kystique : Liz Tullis, université de Toronto

- Maladie pulmonaire pédiatrique : Felix Ratjen; université de Toronto

- Santé environnementale et santé au travail : Catherine Lemière, Université de Montréal, Montréal (Québec)

- Cancer du poumon : Stephan Lam, université de la ColombieBritannique 
rapidly becoming the world expert on the genomics of COPD and lung cancer, Benjamin Raby from Harvard University (Massachusetts, USA) who is also a Canadian and a rising star in the study of the genetics of respiratory disease, and Greg King from the University of Sydney (New South Wales, Australia) who is an honorary Canadian and an expert in lung physiology and imaging. Nick Anthonisen has also agreed to join the Editorial Board to provide wisdom and perspective.

I am excited about taking on this important position and working with Pulsus and such an outstanding group of scientists, clinicians and educators.

\section{REFERENCES}

1. Nocturnal Oxygen Therapy Trial Group. Continuous or nocturnal oxygen therapy in hypoxemic chronic lung disease: A clinical trial. Ann Intern Med 1980;93:391-8.

2. The Intermittent Positive Pressure Breathing Trial Group. Intermittent positive pressure breathing therapy of chronic obstructive pulmonary disease. Ann Intern Med 1983;99:612-20.

3. Anthonisen NR, Connett JE, Kiley JP, et al. Effects of smoking intervention and the use of an inhaled anticholinergic bronchodilator on the rate of decline of $\mathrm{FEV}_{1}$. The Lung Health Study. JAMA 1994;272:1497-505.

4. Anthonisen NR, Manfreda J, Warren CP, et al. Antibiotic therapy in exacerbations of chronic obstructive pulmonary disease. Ann Intern Med 1987;106:196-204.

5. Grant B. "New impact factors yield surprises". The Scientist, June 21, 2010. <http://classic.the-scientist.com/blog/display/57500/> (Accessed on July 8, 2011).

6. Wikipedia. <http://en.wikipedia.org/wiki/Impact_factor> (Accessed on July 11, 2011).

7. Lugtenberg M, Burgers JS, Westert GP. Effects of evidence-based clinical practice guidelines on quality of care: A systematic review. Qual Saf Health Care 2009;18:385-92.

8. Randall G, Taylor DW. Clinical practice guidelines: The need for improved implementation strategies. Health Manage Forum 2000;13:36-42.
- Imagerie pulmonaire : Jonathon Lepisic, université de la ColombieBritannique

- Pneumologie et techniques interventionnistes : Alain Tremblay, université de Calgary

Un éditeur adjoint supplémentaire, le docteur George Rakovich, de l'Université de Montréal, rédige des lignes directrices en vue d'un forum de formation en pathologie et en imagerie cliniques dont il sera responsable. Nous inviterons tous les programmes de pneumologie et de chirurgie thoracique à y participer. Nous avons demandé aux comités directeurs de la Société canadienne du sommeil et de la Canadian Critical Care Society de recommander des éditeurs adjoints dans leur discipline, et nous explorons la possibilité de relations plus officielles entre ces sociétés et la RCP.

Je tiens à profiter de l'occasion pour remercier les éditeurs adjoints et les membres du comité de rédaction sortants pour leur générosité. Bon nombre sont au service de la Revue depuis sa création, il y a 18 ans. Il s'agit de Margaret Becklake, Raymond Bégin et Moira Yeung, membres du comité de rédaction, et de Art Slutsky, Zoheir Bshouty, Donald Cockcroft, Yvon Cormier, Mark FitzGerald, Richard Hodder, Michael Kay, Kieran Killian, Malcolm King, Jean Luc-Malo, Rob McFadden et Bruce Rubin, éditeurs adjoints, dont certains demeureront au comité de rédaction.

En effet, je souhaite la bienvenue aux nouveaux membres du comité de rédaction, soit Avrum Spira, de l'université de Boston (Massachusetts, États-Unis), un Canadien expatrié qui est rapidement en voie de devenir l'expert mondial de la génomique de la MPOC et du cancer du poumon, Benjamin Raby, de l'université Harvard (Massachusetts, États-Unis), également Canadien et une étoile mondiale de l'étude de la génétique des maladies pulmonaires, et Greg King, de l'université de Sydney (Nouvelle-Galles du Sud, Australie), Canadien honoraire et expert de la physiologie et de l'imagerie pulmonaire. Nick Anthonisena également accepté de siéger au comité de rédaction pour lui faire profiter de sa sagesse et de ses points de vue.

Je suis enthousiaste à l'idée d'assumer ce poste important et de travailler avec Pulsus et ce groupe si remarquable de scientifiques, cliniciens et éducateurs.

\section{RÉFÉRENCES}

1. Nocturnal Oxygen Therapy Trial Group. Continuous or nocturnal oxygen therapy in hypoxemic chronic lung disease: A clinical trial. Ann Intern Med 1980;93:391-8.

2. The Intermittent Positive Pressure Breathing Trial Group. Intermittent positive pressure breathing therapy of chronic obstructive pulmonary disease. Ann Intern Med 1983;99:612-20.

3. Anthonisen NR, Connett JE, Kiley JP et coll. Effects of smoking intervention and the use of an inhaled anticholinergic bronchodilator on the rate of decline of $\mathrm{FEV}_{1}$. The Lung Health Study. JAMA 1994:272:1497-505.

4. Anthonisen NR, Manfreda J, Warren CP et coll. Antibiotic therapy in exacerbations of chronic obstructive pulmonary disease. Ann Intern Med 1987;106:196-204.

5. Grant B. "New impact factors yield surprises". The Scientist, le 21 juin 2010. <http://classic.the-scientist.com/blog/ display/57500/> (consulté le 8 juillet 2011).

6. Wikipedia. <http://en.wikipedia.org/wiki/Impact_factor> (consulté le 11 juillet 2011).

7. Lugtenberg M, Burgers JS, Westert GP. Effects of evidence-based clinical practice guidelines on quality of care: a systematic review. Qual Saf Health Care 2009;18:385-92.

8. Randall G, Taylor DW. Clinical practice guidelines: The need for improved implementation strategies. Health Manage Forum 2000;13:36-42. 


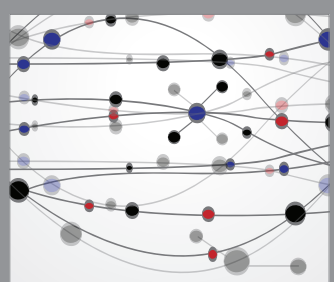

The Scientific World Journal
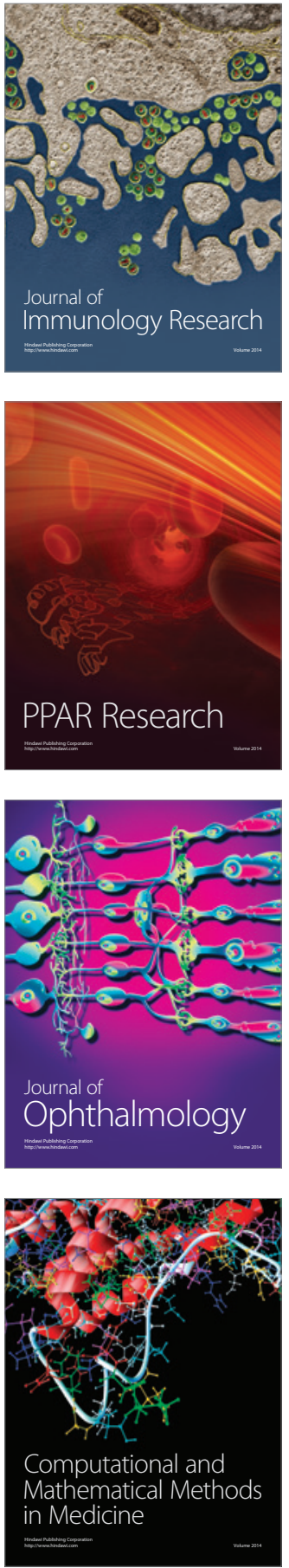

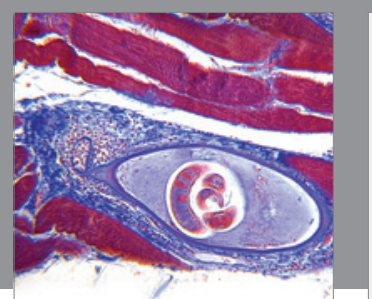

Gastroenterology Research and Practice

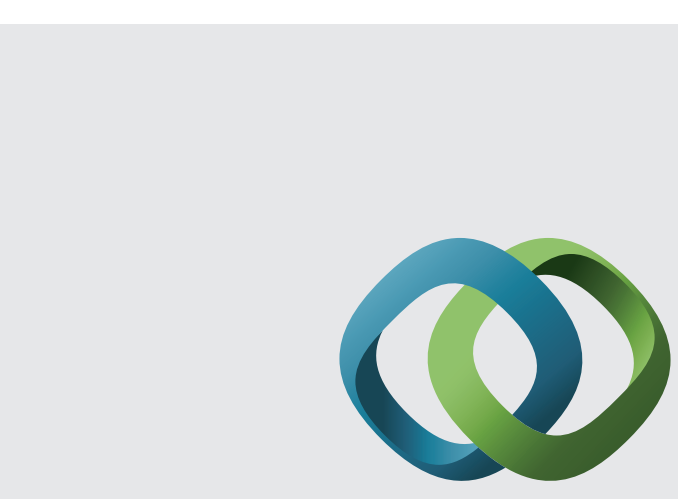

\section{Hindawi}

Submit your manuscripts at

http://www.hindawi.com
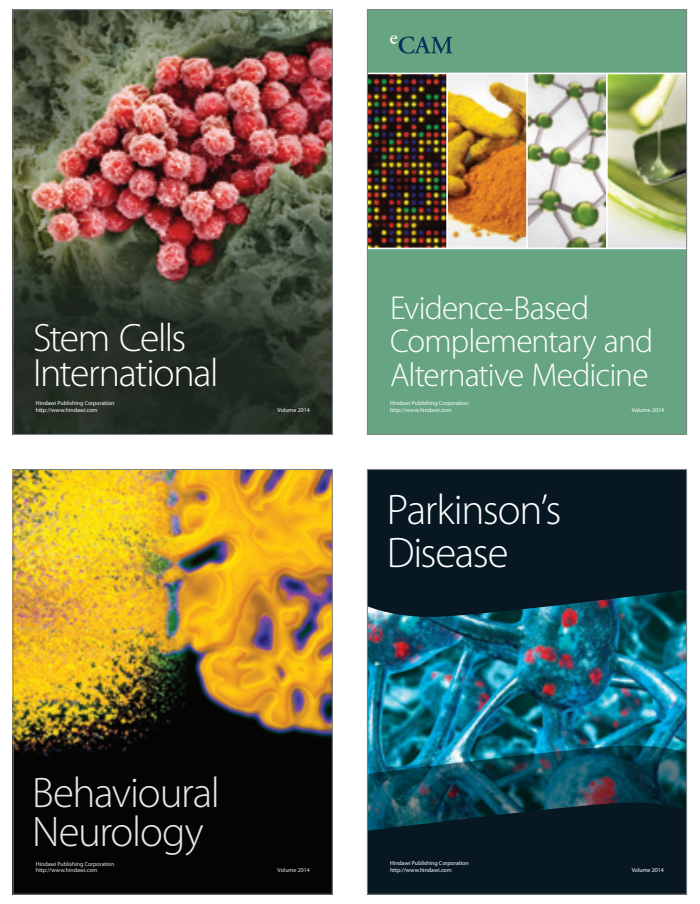
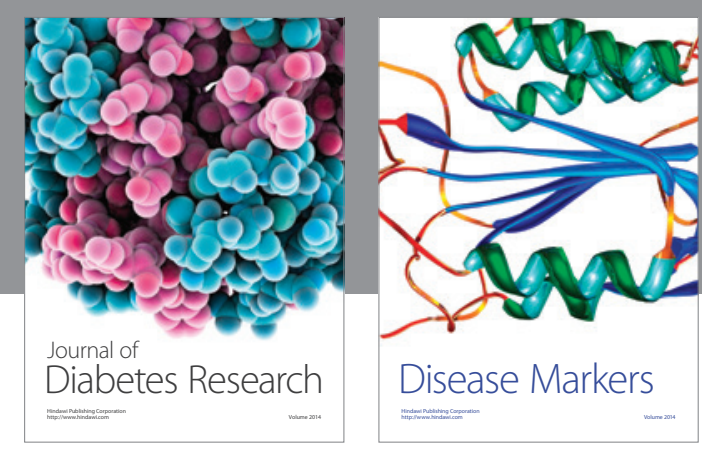

Disease Markers
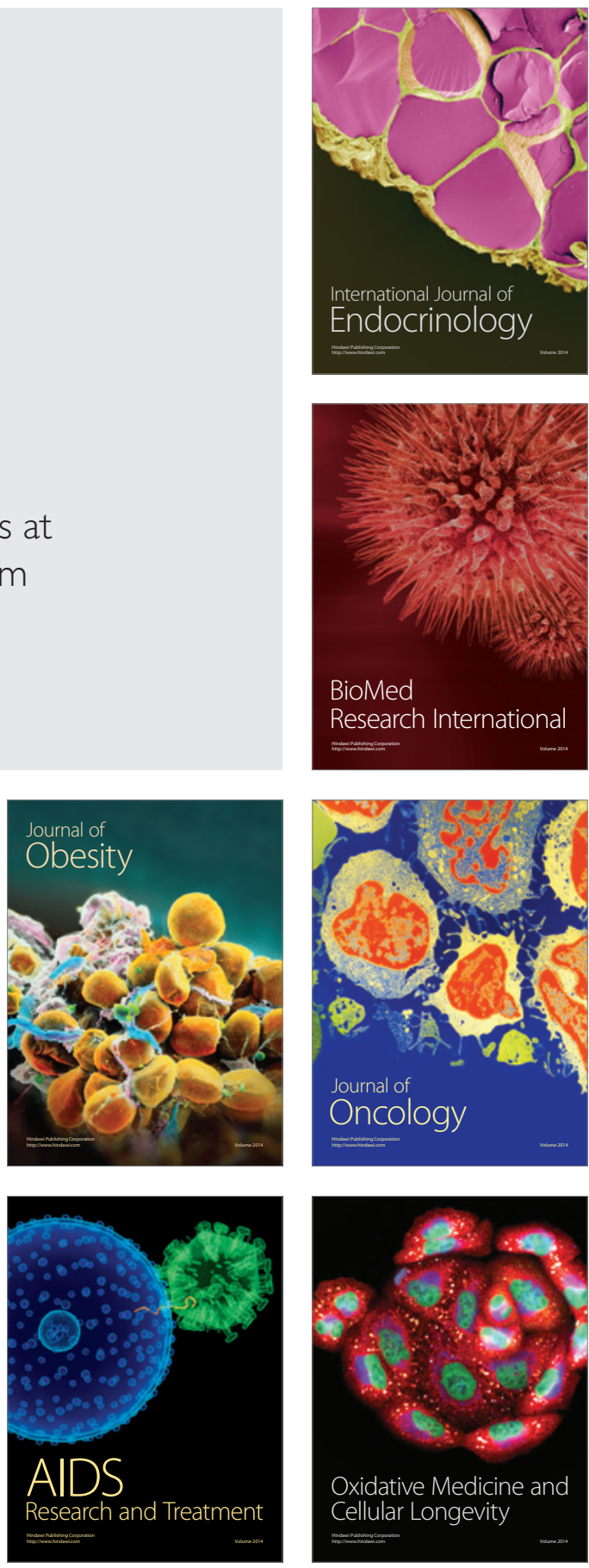